УДК 633.11:631.526.3

(C) 2012

Жемела Г. П., доктор сільськогосподарських наук, професор, Кузнецова О. А., аспірант *

Полтавська державна аграрна академія

\title{
ВПЛИВ СОРТОВИХ ВЛАСТИВОСТЕЙ НА ПРОДУКТИВНІСТЬ ТА ЯКІСТЬ ЗЕРНА ПШЕНИЦІ М'ЯКОЇ ОЗИМОЇ
}

\section{Рецензент - доктор сільськогосподарських наук, професор П. В. Писаренко}

\begin{abstract}
Досліджено вплив сортових властивостей на елементи структури врожайності ( кількість продуктивних стебел, кількість зерен у колосі, масу зерна із колоса, масу 1000 зерен) та формування врожайності пшенииі м'якої озимої. Встановлено, щчо найбільшу кількість продуктивних стебел, кількість зерен у колосі, масу зерна з нього, а також масу 1000 зерен сорти формували в умовах 2011 року. За всіма показниками елементів структури врожсайності найкраще себе проявив сорт Коломак 5. Вплив сорту на урожайність становив 20-25\%.
\end{abstract}

Ключові слова: пшеничя м'яка озима, елементи продуктивності, маса 1000 зерен, кількість зерен у колосі, кількість продуктивних стебел, маса зерна з колоса.

Постановка проблеми. Пшениця м'яка озима $\epsilon$ головною продовольчою культурою в Україні. Прискорений і стійкий ріст об'ємів виробництва зерна - головне завдання працівників сільського господарства. За різного рівня інтенсифікації виробництва сорт завжди був і залишається одним із головних факторів збільшення валових зборів зерна. Для сорту характерний комплекс морфологічних ознак, до яких відносяться врожайність, стійкість до морозів, вилягання, хвороб та шкідників, скоростиглість, хлібопекарські, макаронні та інші технологічні властивості. Отже, сорт, як найбільш економічно вигідний фактор у комплексі агротехнічних заходів швидкого збільшення врожайності і поліпшення якості зерна, в сучасних умовах набуває виключно важливого значення.

Аналіз основних досліджень і публікацій, в яких започатковано розв'язання проблеми. Головною проблемою $є$ розробка теоретичних $\mathrm{i}$ практичних основ сортових технологій вирощування польових культур високої якості продукції 3 мінімальними матеріальними та енергетичними затратами на одиницю врожайності. Вплив сорту на врожайність становить 20-25\%, а може сягати й $50 \%[1,2]$.
В однакових агрокліматичних умовах сорти, які різняться за тривалістю вегетаційного періоду, вимогами до збалансованості елементами живлення, стійкістю до шкідників, хвороб, вилягання, реакцією на несприятливі умови навколишнього середовища, формували неоднакову продуктивність [3, 4].

Збільшення врожайності пшениці озимої супроводжується зміною окремих елементів структури врожайності. Тим самим кожний сорт характеризується своїми особливостями врожайності. Вирішальними чинниками у збільшенні врожайності $\epsilon$ продуктивне кущення, кількість зерен у колосі і маса зерна з одного колоса [5]. Частка колосу у формуванні врожайності зерна становить близько 50 \%. Важливим елементом продуктивності колосу є його довжина, хоча зв'язку даної ознаки з урожайністю не встановлено. Кількість зерен у колосі має тісний кореляційний зв'язок з урожайністю пшениці озимої [4].

Маса зерна 3 колосу також є одним із важливих елементів продуктивності. Дана ознака тісно пов'язана $з$ такими показниками, як кількість зерен у колосі, довжина колосу та умови вирощування. Маса 1000 зерен залежить від умов, зони вирощування, а також сорту. Встановлено пряму залежність між масою 1000 зерен і масою зерна 3 колосу, а також зв'язок між масою 1000 зерен і масою зерна з рослини, кількістю зерен у колосі [5].

Мета досліджень та методика їхнього проведення. Метою наших досліджень було встановити, які сорти пшениці м'якої озимої за елементами структури врожайності збільшують продуктивність.

Експериментальна частина виконувалася протягом 2010-2011 рр. в умовах дослідного господарства «Ювілейне» Полтавської ДАА. Матеріалом для досліджень були районовані сорти пшениці м’якої озимої: Диканька, Коломак 3, Коломак 5, Українка Полтавська, Левада.

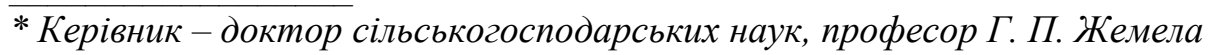




\section{1. Вплив сортових властивостей на елементи структури врожайності пшениці м'якої озимої}

\begin{tabular}{|c|c|c|c|c|c|c|}
\hline \multirow{2}{*}{ Сорт } & \multicolumn{2}{|c|}{$\begin{array}{c}\text { Кількість продуктивних } \\
\text { стебел, шт./ }{ }^{2}\end{array}$} & \multicolumn{2}{|c|}{$\begin{array}{c}\text { Кількість зерен } \\
\text { у колосі, шт. }\end{array}$} & \multicolumn{2}{c|}{$\begin{array}{c}\text { Маса зерна } \\
\text { з колосу, г }\end{array}$} \\
\cline { 2 - 7 } & $2010 \mathrm{p}$. & $2011 \mathrm{p}$. & $2010 \mathrm{p}$. & $2011 \mathrm{p}$. & $2010 \mathrm{p}$. & $2011 \mathrm{p}$. \\
\hline Українка Полтавська & 478 & 472 & 33 & 37 & 1,5 & 1,6 \\
\hline Диканька & 477 & 485 & 35 & 38 & 1,4 & 1,7 \\
\hline Левада & 463 & 435 & 34 & 37 & 1,8 & 2,0 \\
\hline Коломак 5 & 475 & 453 & 39 & 41 & 1,8 & 2,1 \\
\hline Коломак 3 & 455 & 487 & 35 & 39 & 1,5 & 1,7 \\
\hline
\end{tabular}

2. Вплив сортових властивостей на масу 1000 зерен та урожсайність пшениці м'якої озимої

\begin{tabular}{|c|c|c|c|c|c|c|}
\hline \multirow{2}{*}{ Сорт } & \multicolumn{2}{|c|}{ Маса 1000 зерен, г } & \multicolumn{4}{|c|}{ Урожайність, т/га } \\
\cline { 4 - 7 } & & $2011 \mathrm{p}$. & $2010 \mathrm{p}$. & $2011 \mathrm{p}$. & $2010 \mathrm{p}$. & $2011 \mathrm{p}$. \\
\cline { 2 - 7 } & $2010 \mathrm{p}$. & 39,1 & 7,17 & 7,55 & 6,87 & 7,21 \\
\hline Українка Полтавська & 36,7 & 40,2 & 6,68 & 8,24 & 6,25 & 7,94 \\
\hline Диканька & 38,4 & 40,0 & 8,33 & 8,70 & 7,84 & 8,36 \\
\hline Левада & 39,6 & 41,2 & 7,96 & 8,28 & 7,51 & 7,95 \\
\hline Коломак 5 & 39,9 & 39,9 & 8,55 & 9,51 & 8,23 & 9,11 \\
\hline Коломак 3 & 38,4 & 39,4 & \multicolumn{3}{c}{} \\
\hline
\end{tabular}

Польові й фенологічні спостереження проводили згідно з методикою державного сортовипробування сільськогосподарських культур. Попередник - чорний пар. Агротехніка у дослідах загальноприйнята для вирощування пшениці м'якої озимої. Сівбу проводили сівалкою СН-16. Облікова площа ділянки $-50 \mathrm{~m}^{2}$. Повторність чотириразова. Відбір рослин для визначення елементів структури врожайності проводили у фазі повної стиглості. Якість зерна визначали в лабораторії якості зерна Полтавської ДАА.

Результати досліджень. Встановлено, що елементи структури врожайності суттєво залежали від сортових властивостей (табл. 1).

Так, кількість продуктивних стебел, як один із елементів структури врожайності, була найбільшою у 2010 р. у сортів Українка Полтавська

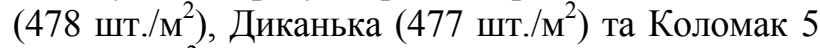
$(475$ шт./м²), найменшою вона була у сорту Коломак 3 (455 шт./м²). Водночас у посушливих умовах, під час достигання зерна у 2011 р., найбільша кількість продуктивних стебел була у сорту Коломак 3 (487 шт./м²), найменшою у сорту Левада $\left(435\right.$ шт./ $\left.\mathrm{m}^{2}\right)$. Кількість зерен у колосі суттєво не залежала від сортових властивостей, за винятком сорту Коломак 5 , у якого в усі роки була найбільша кількість зерен у колосі (39 і 41 шт.). Маса зерна 3 колосу була найбільшою у сортів Коломак 5 і Левада, в інших сортів вона була суттєво меншою.

У сортів пшениці м'якої озимої залежно від погодних умов у період формування й достигання зерна була різна маса 1000 зерен, біологічна $\mathrm{i}$ господарська врожайність (табл. 2).

Так, за сприятливих погодних умов 2010 р. найбільша маса зерна була у сортів Коломак 5 $(39,9$ г) та Левада $(39,6$ г), дещо меншою - у сортів Диканька і Коломак $5(38,4$ г) і найменшою у сорту Українка Полтавська (36,7 г). За посушливих погодних умов у 2011 р. найбільша маса 1000 зерен також була у сорту Коломак $5(41,2$ г) i найменша знов у сорту Українка Полтавська $(39,1$ г). Біологічна і господарська врожайність найбільшою була у сорту Коломак 3 в обидва роки вирощування, найменшою - у сорту Українка Полтавська.

\section{Висновки:}

1. Основними елементами структури врожайності пшениці м'якої озимої є кількість продуктивних стебел на одиниці площі, кількість зерен у колосі, їхня маса та маса 1000 зерен.

2. За всіма показниками структури врожайності найкраще себе проявив сорт Коломак 5.

3. Найбільшу кількість продуктивних стебел, кількість зерен у колосі, масу зерна 3 нього, а також масу 1000 зерен сорти формували за посушливих умов 2011 року. 


\section{БІБЛІОГРАФІЯ}

1. Голик Л. М. Новий зимостійкий сорт пшениці м'якої озимої (Triticum aestivum L.) Волошкова / Л. М. Голик // Сортовивчення та охорона прав на сорти рослин. - 2007. - №6. - С. 11.

2. Гулянов Ю. А. Урожай озимой пшеницы и его структура // Земледелие. - 2003. - №5. C. $10-11$.

3. Коломієць Л. А. Формування адаптивних ознак між сортовими гібридами озимої пшениці
(Triticum aestivum L.) / Л. А. Коломієць. // Copтовивчення та охорона прав на сорти рослин. 2007. - №6. - C. 26-34.

4. Нетіс I. T. Озима пшениця в зоні степу. Херсон: Айлант, 2004. - С. 95.

5. Самофалов А. П. Роль разных элементов структуры урожая в увеличении урожайности озимой пшеницы // Зерновое хозяйство. -2005 . №1. - C. 15-18. 